\title{
POTASSIUM-ARGON AGES OF TERTIARY VOLCANICS ROCKS, TASMANIA
}

\author{
by F.L. Sutherland and P. Wellman
}

(with one table and four text-figures)

SUTHERLAND, F.L. \& WELLMAN, P., 1986 (12:ix): Potassium-argon ages of Tertiary volcanic rocks of Tasmania. Pap. Proc. R. Soc. Tasm., 120: 77-86. https://doi.org/10.26749/rstpp.120.77

ISSN 0080-4703. Australian Museum, 6-8 College St, Sydney. :N.S.W. 2000 and Bureau of Mineral Resources, Geology and Geophysics, P.O. Box 378, Canberra City, A.C.T. 2601.

Sixteen new K-Ar dates are presented from Tasmanian and Bass Basin basalts, more than doubling the previously published number. Eight volcanic regions are described, based on boundaries established on the range of the basalt types contained in each geographic region. Volcanism occurred within the span from Eocene to Miocene (47 to $13+$ $\mathrm{Ma}$ ), but mainly within the time range Middle Eocene to Early Miocene. Alkalibasalts erupted throughout this span and are interspersed with tholeiites (22-3] Ma), fractionated alkaline rocks (22-27 Ma) and rare melilite-bearing varieties (26-35 Ma).

Key Words: basalt, Tasmania, K-Ar ages.

\section{INTRODUCTION}

The Cainozoic igneous rocks of Tasmania are all mafic, but they have a wide range in composition - from tholeiitic to alkaline and including some fractionated types with $\mathrm{Ab} / \mathrm{Ab}+\mathrm{An}$ $>0.55$ (Edwards 1950; Spry 1962; Sutherland 1969a, 1974; Frey et al. 1978). In most areas the flows include a variety of basalt types and their field relationships often suggest separate volcanic episodes with intervening sedimentation and/or erosion (sections, figs 2-3). Previous K-Ar dating consists of 12 dates from five areas (Sutherland $e t$ al. 1975; Green 1976; Sutherland 1976, 1977a; Brown 1977; Cromer 1980). Although 16 new dates (table 1) are presented, more $\mathrm{K} \mathrm{Ar}$ dating is required to define adequately the age of Cainozoic volcanism. The basaltic rocks are assigned here to eight volcanic regions (fig. 1 and table 1) each with geographic boundaries enclosing a different range of basalt types. These volcanic regions fall within the time spans and chemical variations found in petrographic provinces (Rock 1981), but are not clear cut provinces with discrete and distinct chemical character.

Where older dates in the literature are quoted, they have been recalculated using modern values of constants (after Dalrymple 1979), i.e. ${ }^{40} \mathrm{~K} / \mathrm{K}=$ $1.167 \times 10^{-10} \mathrm{moles} / \mathrm{mol}, \lambda \beta=4.962 \times 10^{10} \mathrm{yr}^{-1}, \lambda \epsilon$ $=0.05811 \times 10^{10} \mathrm{yr}^{-1}$. Freshness of samples with respect to loss of radiogenic argon is estimated as $\mathrm{A}$ (completely fresh phases), A-B (fresh K-bearing phases, but with slight alteration of other phases or presence of minor glass), B (some alteration of $\mathrm{K}$-bearing phases) or $\mathrm{C}$ (significant alteration of $\mathrm{K}$-bearing phases). The relevant boundaries of the time scale used here (Hardenbol \& Berggren 1978), involving the new decay constants are: Quaternary - 1.8 Ma; Pliocene - 5.5 Ma; Miocene - 24.6 Ma; Oligocene - 38.0 Ma; Eocene - $54.9 \mathrm{Ma}$; Palaeocene $-66.6 \mathrm{Ma}$.

\section{REGIONS AND AGES}

\section{Northeastern Tasmania (Figs 1 and 2)}

This region contains undersaturated basalts which both cap hills and crop out in the valleys (Brown et al. 1977).

Weldborough area Three basalts give dates of $46.2 \pm 0.6,47.4 \pm 0.5$ and $47.2 \pm 0.6$ Ma (Early Eocene, table 1). Although the rocks are slightly altered (A-B), the age of the volcanism is thought to be $47 \mathrm{Ma}$, because the K-Ar dates agree to within experimental error, and alluvial zircons associated with the basalt give fission track dates that agree with the $\mathrm{K}-\mathrm{Ar}$ age to within experimental error (Yim et al. 1985). This is the oldest Tertiary volcanism identified in Tasmania and the volcanic structure shows considerable erosion (Section A-B, fig. 2).

Analyses of the basalts show that they range from mildly undersaturated to transitional alkaline basalts of sodic affinities (Brown, in McClenaghan et al. 1982). Between Blue Tier and Weldborough Pass the base of the volcanics ranges from 500 to 


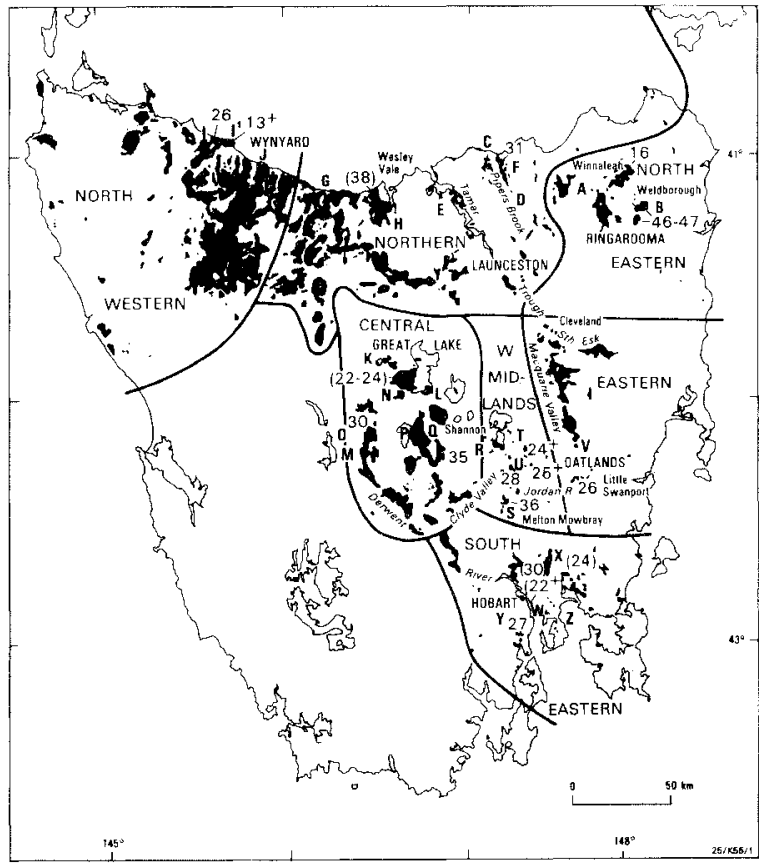

FIG.I - Tasmania showing distribution of basalts (black), Tasmanian volcanic regions (boundary lines), $K$-Ar dates from both this (unbracketed) and previous (bracketed) reports and section lines.

$800 \mathrm{~m} ; 150$ mof agglomerate and tuffs stratigraphically underlie $230 \mathrm{~m}$ of flows. Eruptive centres are thought to be at Weldborough Pass, 2 $\mathrm{km} \mathrm{SW}$ of Forest Lodge and possibly under $\mathrm{Mt}$ Littlechild. Basalts with similar petrology form outlying dykes and cap Grays Hill $16 \mathrm{~km}$ to the west above $420-500 \mathrm{~m}$ altitude. Winnaleah-Ringarooma area.

The basalts here form partly dissected flows giving Middle Miocene ages of 16.0,16.3 and 16.4 \pm 0.3 Ma (Brown 1977; McClenaghan et al. 1982). Analysed flows range from olivine nephelinite to glomeroporphyritic alkali basalt. Flows extend 40 $\mathrm{km}$ along the Ringarooma Valley, with a base from $300 \mathrm{~m}$ (in the south) to $160 \mathrm{~m}$ (in the north) in altitude; they are 20 to $70 \mathrm{~m}$ above the Ringarooma River bed. In places they overlie Early Miocene sediments (Brown 1978).

The younger ages of these basalts compared to the Weldborough hill caps confirm the physiographic interpretations of two ages by Nye (1924), Nye \& Blake (1938) and Edwards (1939), but the actual ages are greater than their estimates.

\section{Northern Tasmania (Figs 1 and 2)}

Basaltic flows lie mainly within valleys draining northward into Bass Strait (Sections C-D, E-F, G-H, fig. 2). They commonly overlie or are interbedded with Cainozoic sediments (Spry 1958; Jennings 1963; Burns 1964; Marshall 1969; Jennings \& Sutherland 1969; Sutherland 1971a) and in places the basalts flowed into dammed river systems (Sutherland 1980). The flows are olivine nephelinites ranging through alkali basalts to quartz tholeiite.

In the eastern part, at Pipers Brook the basalts extend from $600 \mathrm{~m}$ to below sea-level over a distance of $20 \mathrm{~km}$. Alkali olivine basalt is overlain by tholeiitic flows, and capped by Cainozoic sediments, alkaline basalt and olivine nephelinite. A reasonably fresh quartz tholeiite (A-B) from the lower sequence gave a date of $30.7 \pm 0.4 \mathrm{Ma}$ (Middle Oligocene, table 1). The interbedded nonmarine sediments here at Pipers Brook and elsewhere in the region (Burns 1964; Sutherland 1973a) are thought to be related to nearby high sea-levels in the mid-Tertiary. Some flows overlying these sediments are extensively dissected and weathered, so they may be older than the less dissected Middle Miocene flows of the Winnaleah region.

The Early Oligocene basalt fill in Pipers Brook supports the contention that many of the valleys draining into Bass Basin were already blocked by lavas, which impeded ingress of midTertiary high seas (Sutherland 1973a). These blocked valleys only allowed minor Miocene marine incursions on to the coast, judging by the limited outcrops of marine sediments (Quilty 1972). The evidence suggests that volcanism within the drainage system into Bass Strait mostly occurred from Middle Eocene to at least Early Miocene time.

In the western part, a lower porphyritic olivine basalt flow in the Wesley Vale sequence gave a $38.1 \pm 0.6 \mathrm{Ma}$ date (latest Eocene, Cromer 1980). Nearby basalts at East Devonport may be of similar age because they are interbedded with palaeontologically dated Late Eocene-Early Oligocene sediments (Sutherland 1973a).

Slightly older alkali basalts may be present in the Longford Basin where they are interbedded with sediments which contain Middle to Late Eocene palynological assemblages, but sampled basalts proved unsuitable for K-Ar dating (Matthews 1983).

\section{Northwestern Tasmania (Figs 1 and 2)}

The largest volume of Cainozoic lava is in northwestern Tasmania. The flows range from 
TABLE 1

K-Ar Ages for Samples from Tasmanian Regions

Sample No. and Location

Northeast Tasmania:

BT2, $5.5 \mathrm{~km}$ SSE of Weldborough

BT4, $7.5 \mathrm{~km} \mathrm{~S}$ of Weldborough

BT5, 6.6km SE of Weldborough

Northern Tasmania:

PB1, 2.2km NW of Pipers Brook

Northwestern Tasmania:

TCl, Tollemore quarry, Table Cape

SCl, Shekleton Creek, Boat Harbour

Central Tasmania

ST1, Haystack, Shannon Tier

LU, Laughing Jack Marsh,

$10.3 \mathrm{~km}$ WSW of Bronte

Southeastern Tasmania:

SB1, Sandy Bay $4 \mathrm{~km}$ SE of Hobart GPO

CRI, Coal River, $3 \mathrm{~km}$ NW of Campani

Western Midlands and Eastern Tasmania:

BW 1, Big White Hill, 4.7km NNE

Melton Mowbray
1 , Rose Hill Farm, $4 \mathrm{~km}$ WNW

, Rose Hill

BH I, Barwicks Hill, $3.5 \mathrm{~km}$ WNW of Oatlands

FH1, Fernleigh Hill, 4km WNW of Oatlands

PP1, Pencil Point, 9km ESE

$$
\text { of Andover }
$$

CN1, Cormorant No.1, Core 11, $8100-8116 \mathrm{ft}$
Longitude

Alt.

$\mathrm{S}$

$41^{\circ} 14.4$

$41^{\circ} 16.0^{\prime \prime}$

$41^{\circ} 14.7^{\prime}$

$147^{\circ} 55.3$

$147^{\circ} 55.2^{\prime}$

$147^{\circ} 57.1^{\prime}$

A-B

A-B

$0.691,0.691$

0.771

$41^{\circ} 04.2^{\prime}$

$147^{\circ} 09.7^{\prime}$

$40^{\circ} 57.1^{\prime}$

$41^{\circ} 00^{\prime}$

$145^{\circ} 42.3^{\prime}$

A-

$0.291,0.292$

$42^{\circ} 11.1^{\prime}$

$42^{\circ} 09.5^{\prime}$

$146^{\circ} 56.9^{\prime}$

$146^{\circ} 22.3$

A-B

$1.276,1.281$

$1.125,1.124$

$42^{\circ} 55.9^{\prime}$
$42^{\circ} 39.0^{\prime \prime}$

$147^{\circ} 21.4^{\prime}$

$147^{\circ} 27.2^{\prime}$

A

A-B
A

$1.589,1.587$

$1.123,1.119$

K

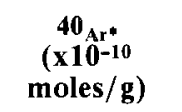

${ }_{\text {total }}^{40_{\mathrm{Ar}}^{*}} 4 \mathrm{Ar}_{\mathrm{Ar}}$

Age
\pm I.S.D.

(Ma)

moles/g)

.5951

$\begin{array}{lll}0.59511 & 0.879 & 46.2 \pm 0.6 \\ 0.57408 & 0.788 & 47.3+0.5\end{array}$

$\begin{array}{lll}0.64299 & 0.870 & 47.4+0.6\end{array}$

$\begin{array}{lll}0.63815 & 0.862 & 47.0+0.6\end{array}$

$\begin{array}{lll}0.15680 & 0.709 & 30.7 \pm 0.4\end{array}$

$\begin{array}{lll}0.29616 & 0.815 & 13.3+0.2\end{array}$

$0.5169-0.927$

$\begin{array}{lll}0.98416 & 0.946 & 35.4 \pm 0.4\end{array}$

$\begin{array}{lll}0.59110 & 0.910 & 30.1+0.4\end{array}$

A-B $\quad 2.680,2.680$

1.76

1.24160

$0.1379^{*}$

0.968

$26.5+0.3$

$42^{\circ} 25.9^{\prime}$

$147^{\circ} 11.9^{\prime}$

$147^{\circ} 14.2^{\circ}$

$A-B$

$42^{\circ} 22.4^{\prime \prime}$

$147^{\circ} 14.2$

$1.288,1.286$

$1.214,1.213$

$0.8197 \mathrm{I}$

0.58493

0.570

0.901

$42^{\circ} 16.9^{\prime}$

$147^{\circ} 20.3^{\prime}$

B

0.89760

0.905

$25.0+0.3$

$42^{\circ} 16.9^{\prime}$

$147^{\circ} 19.6^{\circ}$

$2.060,2.050$

0.73818

0.945

$24.3 \pm 0.3$

$42^{\circ} 21.2^{\prime}$

$147^{\circ} 33.3^{\prime}$

A-B

$0.497,0.495$

0.2220

0.416

$25.6 \pm 0.2$

$39^{\circ} 34.3^{\prime}$

$145^{\circ} 31.8$

A-B

$6.874,6.866$

2.690

0.784

$22.4+0.1$

$*\left(x_{10}^{-5} \mathrm{cc} / \mathrm{gm}\right)$ 

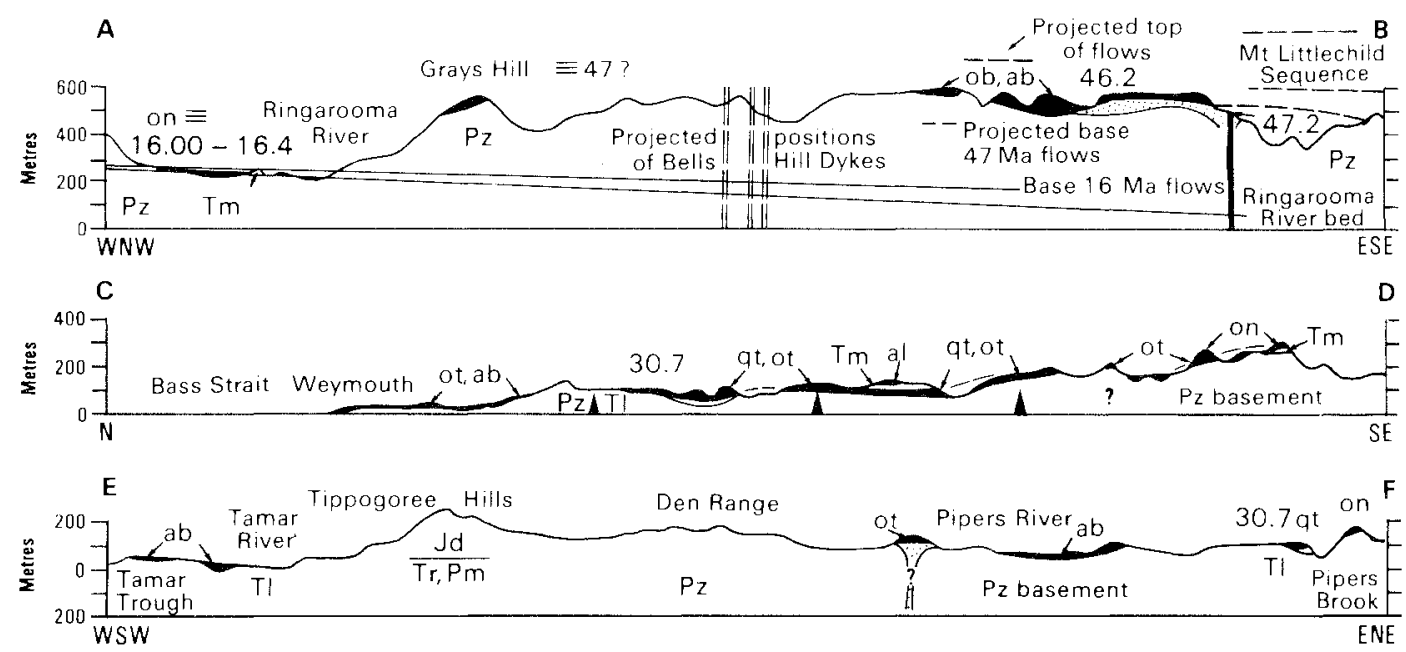

G Don Heads Devonport Wesley Vale Rubicon $\mathbf{H}$
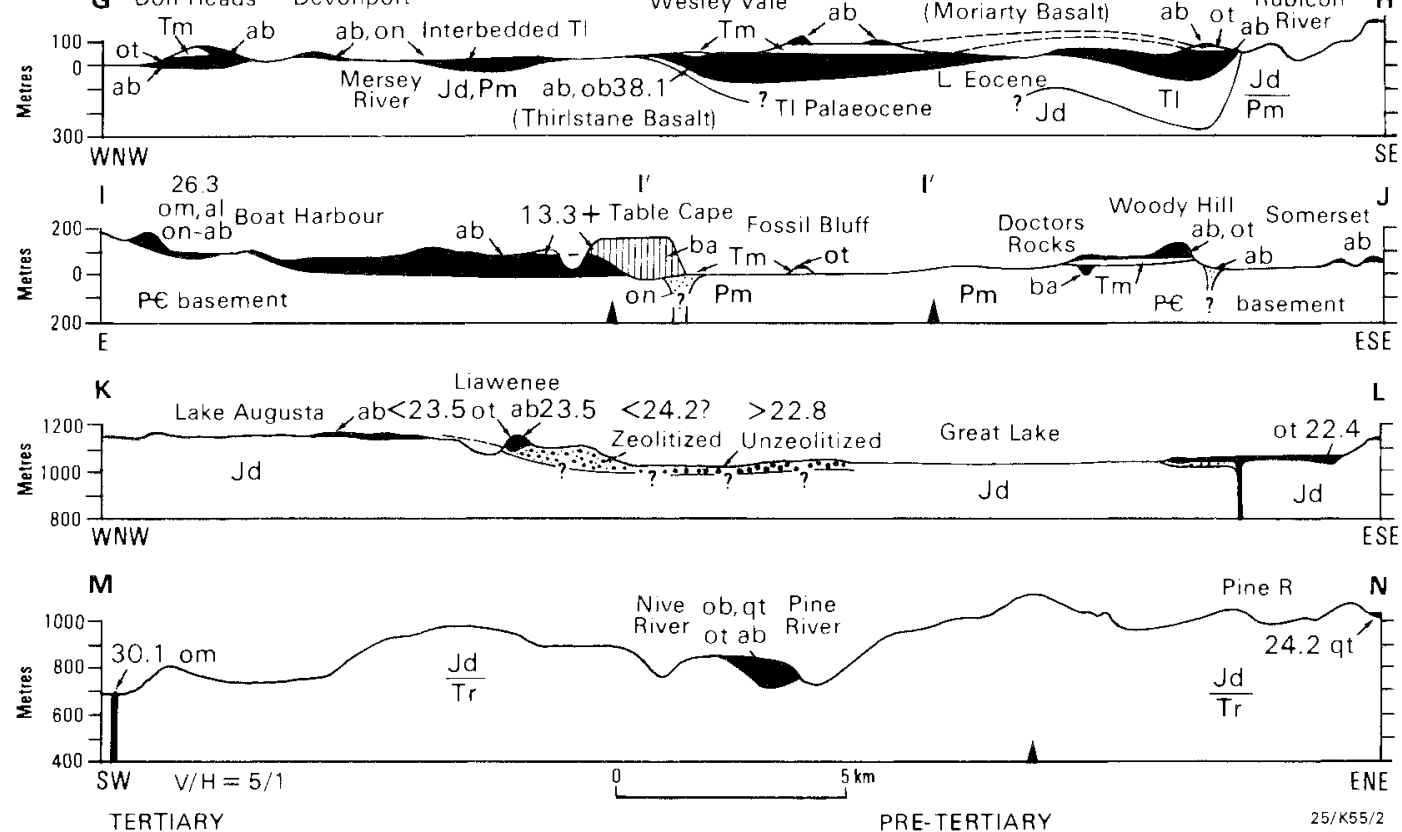

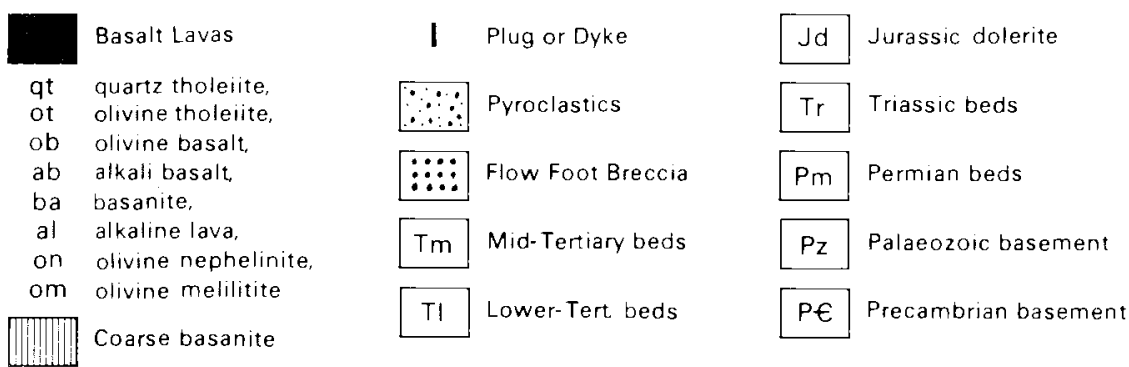

FIG.2 - Sections through daled basalt regions, $N E, N, N W$ and central Tasmania, in relation to physiography, petrology and volcanic sources.
Notches on the section base indicate dog-legs in the section line to show basalt sequences to best advaniage. 
olivine melilite nephelinite to olivine tholeiite. The lavas overtopped the valleys to form an extensive lava plain, including Late Eocene-Early Oligocene sediments (Brown \& Forsyth 1984). This plain has an upper surface near $100 \mathrm{~m}$ in altitude at Wynyard and rises to the south, reaching $750 \mathrm{~m}$ altitude 70 $\mathrm{km}$ inland (Burns 1964; Barton et al. 1966; Sutherland 1969b; Gee 1971, 1977; Brown \& Forsyth 1984). In the far northwestern part of the island lavas are less extensive but are notable for the high proportion of aquagene basalts erupted into mid-Tertiary seas (Sutherland \& Corbett 1967; Quilty 1972; Sutherland 1969b, 1973a, 1980).

Between Wynyard and Somerset limburgitic basalts are overlain by latest Oligocene-earliest Miocene marine sediments and minor aquagene breccias of olivine tholeiite (Gee 1971, 1977; Sutherland 1973a). These are overlain by a thick sequence of basalt flows (Section I-J, fig. 2), weathered for the most part. West of Table Cape the basalt succession has been eroded and lateritised. A thick fill $(177 \mathrm{~m})$ of coarse unlateritised basanite overlies nephelinitic pyroclastics at Table Cape. A slightly altered sample of this basanite (B) gave a Middle Miocene age of $13.3 \pm 0.2 \mathrm{Ma}$ (table 1 ).

In the sequence between Table Cape and Boat Harbour, an olivine melilite nephelinite flow overlies an anorthoclase-bearing nepheline mugearite in Shekleton Creek, and is the source of the gem zircon and corund um of the district (Gee 1971; Matthews 1973; Hollis \& Sutherland 1985). Dating of the Shekleton Creek melilite nephelinite gave $26.3 \pm 0.3 \mathrm{Ma}$. Thus, the basalts in the Wynyard region include Late Oligocene or older alkaline rocks (>26.3 Ma), Early Miocene olivine tholeiite and Middle Miocene nephelinite-basanites $(>13.3 \mathrm{Ma})$.

\section{Central Tasmania (Figs 1, 2 and 3)}

This region contains la vas that were erupted onto the Central Plateau, and also lavas that descended south from the plateau, into the Derwent drainage west of the Clyde Valley. Lavas range from olivine nephelinite to quartz tholeiite and there are rare plugs of olivine melilitite and melilite nephelinite. The flows extend over $80 \mathrm{~km}$, being extruded both subaerially and into lava-dammed rivers in sequences up to $400 \mathrm{~m}$ in thickness (Spry 1962; Sutherland \& Hale 1970; Sutherland 1973b 1980). Sutherland et al. (1973) dated five lavas from the predominantly tholeiitic sequence near Great Lake (Sections K-L, M-N, fig. 2). As the ages of the lavas range from 22.4 to $24.2 \pm 0.6 \mathrm{Ma}$, most of the lavas of the region are likely to be Late Oligocene- earliest Miocene in age

Plugs of olivine (monticellite) nepheline/ melilite rocks are known at Shannon Tier on the eastern side of the region (Twelvetrees 1902; Edwards 1950). A sample from one (A-B) gave a $35.4 \pm 0.4$ Ma age (Early Oligocene, table 1 ). A plug of olivine nepheline melilitite (A) at Laughing Jack Marsh (Sutherland 1973b; Brey \& Green 1975; Frey el al. 1978) gave a younger, 30.1 \pm Ma age (Middle Oligocene, table 1). Both these highly silica-undersaturated intrusions are therefore older than the dated flows in the region (Sections $\mathrm{M}-\mathrm{N}$, $\mathrm{O}-\mathrm{P}, \mathrm{Q}-\mathrm{R}$, figs 2 and 3).

\section{Western Midlands (Figs 1 and 3)}

Basalts here range from olivine nephelinite to alkali basalts and include fractionated alkaline lavas. On the southwestern side undersaturated lavas extend from the Central Plateau at around $900 \mathrm{~m}$ near Interlaken to $420 \mathrm{~m}$ altitude near Oatlands (Forsyth 1976). The basalts at different levels (Sections S-T, U-V, fig. 3) differ petrologically and many are related to local centres (Sutherland 1971b, 1984). Although originally in valleys many now form cappings to hills; individual flows can be traced from hilltop to hilltop for up to $10 \mathrm{~km}$. The flow at Big White Hill north-northeast of Melton Mowbray gave a date of $36.3 \pm 0.5 \mathrm{Ma}$ (Early Oligocene, table 1). It is up to $90 \mathrm{~m}$ thick and filled a valley. It caps two isolated hills close to the Jordan River - its base is 500 to 380 m altitude and well above the Jordan River at $210 \mathrm{~m}$. The Jericho plug at Rose Hill Farm some $6 \mathrm{~km}$ to the north gave a date of $27.6 \pm 0.4 \mathrm{Ma}$ (Late Oligocene, table 1). It is at $400 \mathrm{~m}$ altitude and is the inferred feeder for a petrologically similar flow filling an ancestral gully of Rose Hill Creek at 420 to $500 \mathrm{~m}$ altitude some 2 $\mathrm{km}$ to the west. About $13 \mathrm{~km}$ to the northeast, near Oatlands township two flows overlie volcanic breccias (Sutherland 1984). The eastern flow (at Barwicks Hill) is a nepheline hawaiite flow, with a base at 420 to $460 \mathrm{~m}$; a sa mple (B) gave a minimum age of $25.0 \pm 0.3 \mathrm{Ma}$ (Late Oligocene, table 1). The western flow (at Fernleigh Hill; Sutherland 1984 and Forsyth 1984, p. 154) according to field evidence is a younger hawaiite flow which has a base at 540 to $560 \mathrm{~m}$. Samples are rarely fresh (B) and give a minimum date of $24.3+0.3 \mathrm{Ma}$ (OligoceneMiocene boundary, table 1). The undersaturated lavas in this region therefore mostly give Middle to Late Oligocene ages, considerably older than suggested by Edwards (1939) on physiographic interpretations. 
$\mathrm{O}$

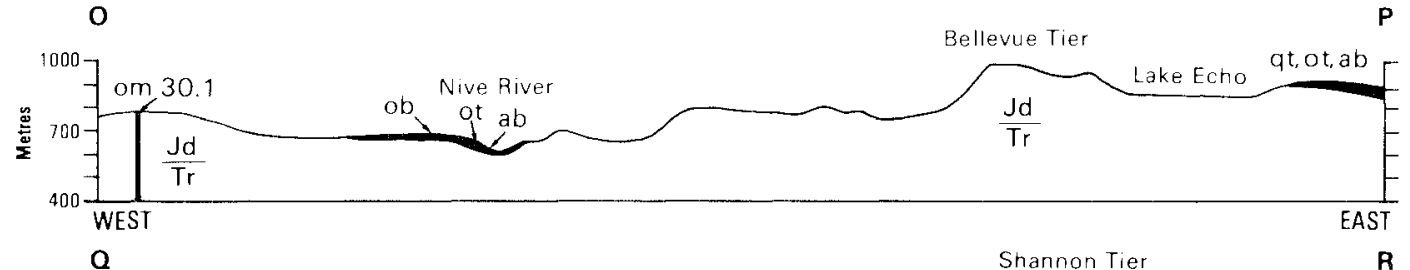

Q

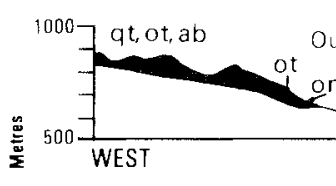

Shannon Tier R

Ouse River

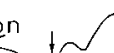

S

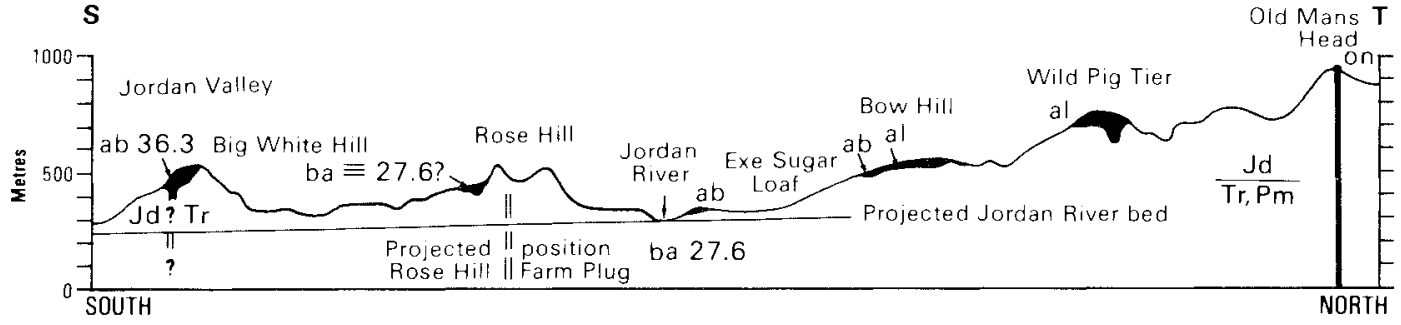

$U$ Fernieigh Barwicks Hill Vincents
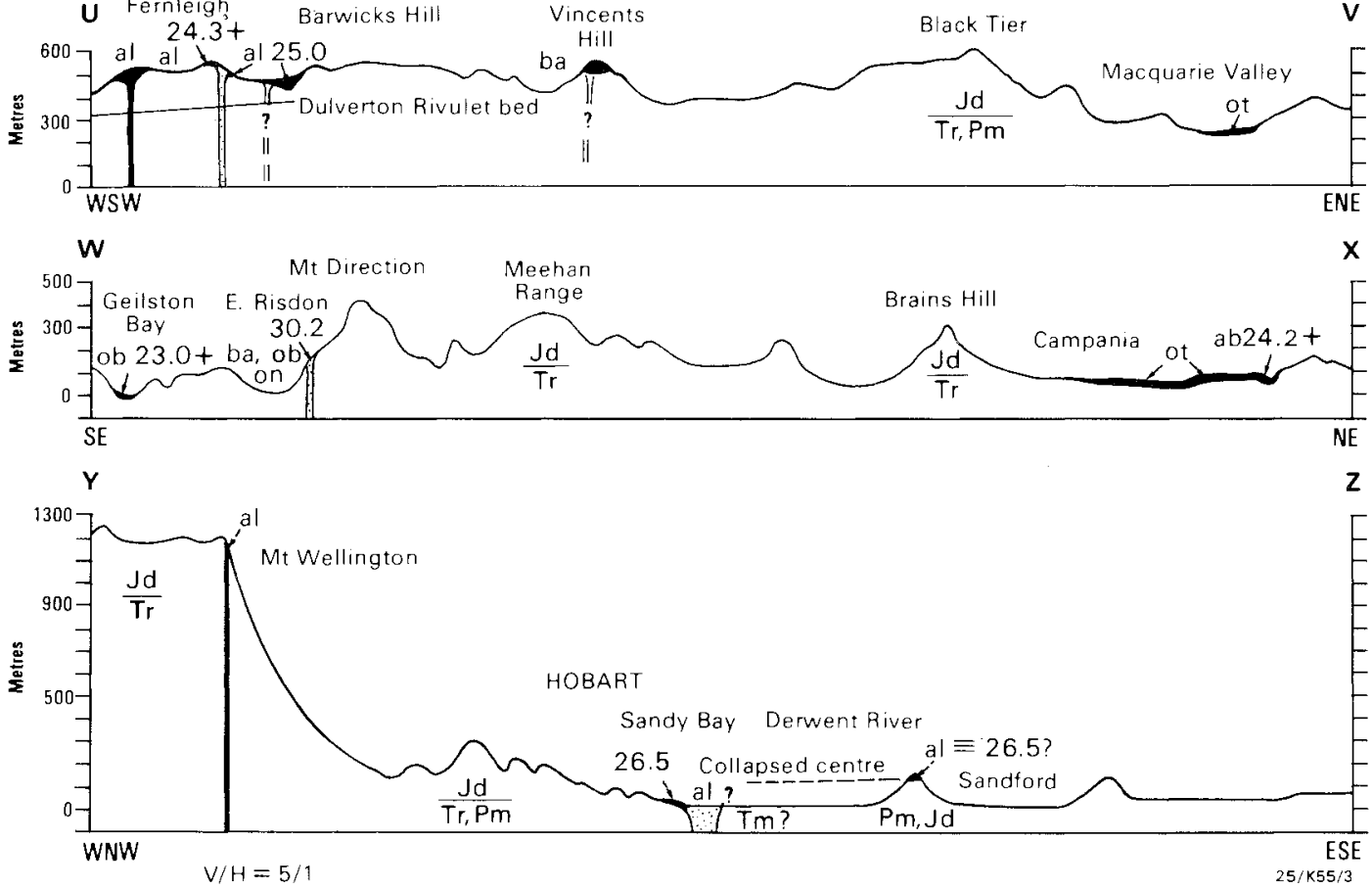

FIG.3 - Section lines through central, western Midlands, eastern and southern Tasmania. Legend as in Fig. 2. 


\section{Eastern Tasmania (Figs 1 and 3)}

Tholeiitic lavas are more common than undersaturated lavas in this region and flowed for $50 \mathrm{~km}$ north down the ancestral Macquarie and South Esk and east down the Little Swanport River valleys. They descend from about $400 \mathrm{~m}$ to between 180 and $230 \mathrm{~m}$ altitude in the north. Here, near Cleveland, the flows fill valleys cut into sediments dated palynologically as Middle to Late Eocene (W.L. Matthews and S.M. Forsyth, pers. comm.). The lateritised flows form part of the Woodstock Surface of probable Pliocene age (Nicolls 1960; Matthews 1974). Samples collected were not fresh enough for K-Ar dating. Following Nye \& Blake (1938) we believe that most of these tholeiitic basalts may be younger than the Oligocene alkaline lavas of the western midlands immediately to the southwest (Section $U-V$ ). We infer that they are probably Early to Middle Miocene in age. However, in the south at Pencil Point near Andover, an unusual olivine tholeiite flow erupted from a centre; it carries mantle lherzolite xenoliths (Sutherland 1974). This basalt (A-B) gives a date of $25.6 \pm 0.2 \mathrm{Ma}$ (table 1). This indicates some Late Oligocene overlap between the tholeiites and the alkaline eruptions of the western Midlands even though quartz tholeiite overlies nepheline mugearite near Lemont.

\section{Southeastern Tasmania (Figs 1 and 3)}

The most widespread flows are olivine tholeiites erupted into the valleys of the lower Derwent and Coal Rivers (McDougall 1959; Sutherland 1976, 1977a, 1980). Some of these lavas eruptedinto or flowed into water. No suitable tholeiitic rocks for $\mathrm{K}-\mathrm{Ar}$ dating have been found. Tholeiites overlie an alkali basalt near Campania in the Coal Valley (Section W-X, fig. 3); the alkali basalt gives a minimum $24.2 \pm 1.0 \mathrm{Ma}$ age (earliest Miocene, table 1; Sutherland et al. 1973; Green 1976; Sutherland 1977a) and a sample of considerably altered tholeiite (C) gave an age older than $10 \mathrm{Ma}$ (D.C. Green and F.L. Sutherland, unpublished). The tholeiitic lavas therefore may be latest Oligocene or Early Miocene in age.

Alkali basalts and fractionated alkaline lavas form short valley flows and pyroclastic centres around Hobart from D'Entrecasteaux Channel to Tasman Peninsula (Brill \& Hale 1954; Spry 1962; Sutherland 1985). Amphibole from a tuff interbedded in the East Risdon volcanic centre gave a $30.2 \pm 1.0 \mathrm{Ma}$ age (Middle Oligocene; Sutherland 1976; Green 1976). A nearby olivine basalt flow

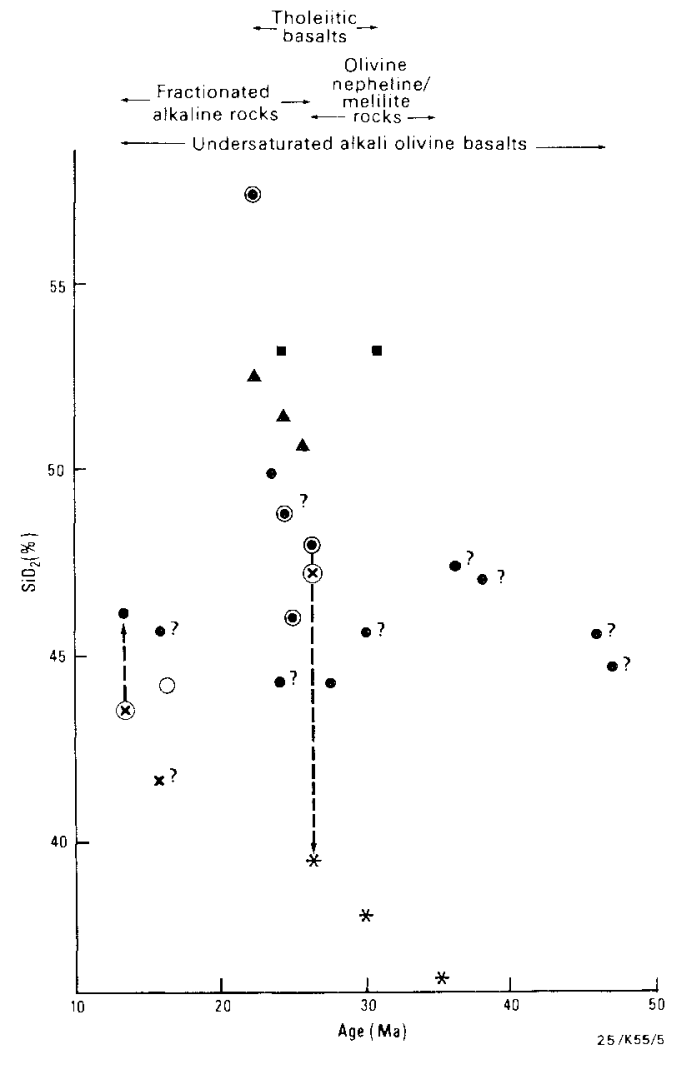

FIG.4 - $\mathrm{SiO}_{2}$ versus age (Ma) plots for dated Tasmanian basalts, showing petrographic types vis. olivine melilitite/nephelinite rocks (asterisks), olivine nephelinites (crosses), basanites (open circles), olivine tholeitites and transitional basalts (filled triangles) and quartz tholeiites (filled squares). More fractionated alk aline rocks of these lineages $(A b / A b+A b>0.55)$ are indicated by circles enclosing the lineage type. Dated rocks with no available chemical analyses are shown at approximate $\mathrm{SiO}_{2}$ content, based on analogy with petrographically similar analysed rocks taken from the cited literature, and are indicated by question marks. Age spreads of highly undersaturated melilite-bearing rocks, undersaturated alkali basalts, tholeitic basalts and more fractionated alkaline rocks are shown by tied arrows. Rocks immediately underlying and closely connected with dated basalts are linked by dashed arrows.

overlying a fossil marsupial site gave a minimum age of $23.0 \pm 0.5 \mathrm{Ma}$ (Tedford et al. 1975). The well-studied Sandy Bay volcanic centre (Charles Darwin, reported in Banks 1971; Johnston 1888; 
Spry 1955) overlies Cainozoic sediments, with a palynological age of younger than Eocene and probably Yallournian (Oligocene; Gill 1962). The top flow of mafic nepheline benmorite (Sutherland $1974,1976)$ has fresh rock (A-B) yielding a date of $26.5 \pm 0.3 \mathrm{Ma}$ (Late Oligocene, table 1). The dated alkaline volcanics in southeastern Tasmania (Sections W-X, Y-Z, fig. 3) are therefore MidOligocene to Early Miocene in age.

\section{Bass Basin}

In Bass Basin, a similar volume of basalts to that occurring above sea level in Tasmania is interbedded with the sediments (Robinson 1974; Brown 1976). Palaeontological dating suggests that this volcanism ranges from Eocene to Miocene. This is a similar time span to that shown by dated on-shore Tasmanian basalts. The oldest dated Tasmanian basalt (47 Ma, NE Tasmania) is significantly younger than the graben formation and Late Cretaceous-Early Palaeocene sedimentation that extends from Bass Basin into the Tasmanian mainland (Moore et al. 1984).

The volcanic successions intersected in Bass Basin bore holes are generally too altered for satisfactory dating, but an intrusion in Early Eocene sediments in Cormorant No.I bore (B.R Brown 1976, fig. 5) seemed suitable. The intrusion is an unusual alkaline rock with no known counterpart on-shore in Tasmania; it grades from a picritic cumulate with a hydrous altered groundmass to a coarser analcime-bearing highly sodic and felsic gabbro. It appears to represent a monchiquite intruded into and fractionated within the wet sediments. Biotite separated from the rock is only slightly altered and gives a minimum date of $22.4 \pm 0.1 \mathrm{Ma}$ (unpublished data, Bureau of Mineral Resources). The date (table 1) suggests Early Miocene alkaline activity towards the close of Bass Strait volcanism. This activity may include an Early-Middle Miocene monchiquite intrusion at Portland, Victoria (Glenie \& Reed 1962), dated as at least 17.5 Ma (Harding 1966).

\section{PETROLOGY AND AGES}

The dating and petrological information discussed above is summarised in figure 4. Initial, restricted and mildly alkaline basaltic volcanism in the Early Eocene (Weldborough area; $47 \mathrm{Ma}$ ) was followed by more widespread undersaturated volcanism from Middle to Late Eocene to earliest Oligocene (Northern, Central and Midlands regions: 35-38 Ma). Strongly undersaturated to saturated lavas were erupted in the Early-Middle
Oligocene (Central, Southeastern, Northwestern and Northern regions: 26-35 Ma). This widespread volcanism continued through the Late OligoceneEarly Miocene but overlapped with some activity leading to fractionated alkaline lavas (Midlands, Eastern, Southeastern, Bass Basin regions: 22-27 Ma). A final phase of undersaturated volcanism is recognised in northern Tasmania around the Middle Miocene (Ringarooma-Winnaleah, Table Cape regions: 13-16 Ma). The total volume of lava erupted in Tasmania was only about $400 \mathrm{~km}^{3}$ (Sutherland 1969a).

The main 'magmatic message' emerging from the dating of Tasmanian Tertiary volcanic rocks is that oversaturated basalts (approximating to $\mathrm{SiO}_{2}$ contents above $50 \%$ in figure 4 ) are virtually confined to the Mid-Tertiary episodes (2l to 31 $\mathrm{Ma}$ ). If these tholeiites represent relatively high degrees of partial melting of mantle source rocks (Frey et al. 1978) this correlates with an OligoceneEarly Miocene peak of volcanism. The only other rock with $\mathrm{SiO}_{2}$ significantly over $50 \%$ is the highly fractionated sodic gabbro from Cormorant-1 well in Bass Strait. However, this rock is derived from an undersaturated parent and belongs to the waning stage of volcanic activity in Bass Strait.

\section{ACKNOWLEDGEMENTS}

The samples were dated by the Geochronology Section of the Australian Mineral Development Laboratories at Frewville, South Australia using funds supplied by the Bureau of Mineral Resources, Canberra (12 samples) and the Australian Museum Trust, Sydney, N.S.W. (2 samples). Help in collecting Tasmanian samples was given to Sutherland around Weld borough by W.W.-S. Yim, Geology Department, University of Tasmania and K. Morrison, Aquitaine-Amdex; around Oatlands by S.M. Forsyth, Geological Survey of Tasmania; and at Boat Harbour by W.L. Matthews, Geological Survey of Tasmania, Hobart. N.R. Kemp, Tasmanian Museum, Hobart, supplied the Table Cape sample.

D.C. Green, Tasmanian Mines Department, gave permission to quote analytical details of the Coal River basalt from an unpublished Queensland University report. The Cormorant-1 well sample, Bass Strait, was supplied by K. Lockwood, Bureau of Mineral Resources, Canberra and permission to use the results was given by the Acting Director, Bureau of Mineral Resources. The paper is published with the permission of the Director, Bureau of Mineral Resources. The figures were drafted by G.A. Clarke of B.M.R. Cartographic Section. 


\section{REFERENCES}

BANKS, M.R., 1971: A Darwin manuscript on Hobart Town. Pap. Proc. R. Soc. Tasm. 105: 5-19.

BARTON, C.M., BURNS, K.L., GEE, R.D., GROVES, D.I., GULLINE, A.B., JENNINGS, D.J., LONGMAN, M.L., MARSHALL, B., MATTHEWS, W.L., MOORE, W.R., NAQVI, I.H. \& THREADER, V.M., 1966: Geological atlas I mile series, Mackintosh sheet $44(8014 \mathrm{~N})$.

BREY, G. \& GREEN, D.H., 1975: The role of $\mathrm{CO}_{2}$ in the genesis of olivine melilitite. Contr. Mineral Petrol. 49: 93-103.

BRILL, K.G. \& HALE, G.E.A., 1954: The geological map of northwestern end of Tasman Peninsula - a revision. Pap. Proc. R. Soc. Tasm. 88: 179-184

BROWN, A.V., 1977: Preliminary report of age determinations of basalt samples from the Ringarooma 1:50,000 sheet, Tasmania. Tasm. Dept Mines Rept 1977/25 (unpubl.)

BROWN, A.V., 1978: Tertiary lead and basin Winnaleah map sheet. Tasm. Dept Mines Rept 1978/7 (unpubl.).

BROWN, A.V., MCCLENAGHAN, M.P., ET AL., 1977: Geological atlas 1:50,000 series. Ringarooma, sheet $32(8412 \mathrm{~N})$.

BROWN, A.V.\& FORSYTH, S.M., 1984: Chemistry of Tertiary basalt and palynology of interbedded sediments from B.H.P. drill holes, E.L. 33/79. Tasm. Dept Mines Rept 1984/39 (unpubl.).

BROWN, B.R., 1976: Bass Basin - some aspects of the petroleum geology. In LESLIE, R.B., EVANS, H.J. \& KNIGHT, C.L., (Eds): ECONOMIC GEOLOGY OF AUSTRALIA AND PAPUANEW GUINEA - 3. PETROLEUM. Aust. Inst. Min. Metall., Parkville, Victoria: 67-82.

BURNS, K.L., 1964: One mile geological map series K/55-6-29, Devonport. Explan. Rept Geol. Surv. Tasm.

CROMER, W.C., 1980: A late Eocene basalt from northern Tasmania. Search 11: 294-295.

DALR YMPLE, G.B., 1979: Critical tables for conversion of K-Ar ages from old to new constants. Geology 7: $558-560$

EDWARDS, A.B., 1939: The age and physiographical relationships of some Cainozoic basalts in central and eastern Tasmania. Pap. Proc. R. Soc. Tasm. (1938): $175-200$

EDW ARDS, A.B., 1950: The petrology of the Cainozoic basaltic rocks of Tasmania. Pap. Proc. R. Soc. Vict. 62: 97-120.

FORSYTH, S.M., 1976: Geological atlas 1:50,000 series. Oatlands, sheet $68(8313 \mathrm{~S})$.

FREY, F.A., GREEN, D.H. \& ROY, S.D., 1978: Integrated models of basalt petrogenesis: a study of quartz tholeites to olivine melilitites from south eastern Australia utilizing geochemical and experimental petrologic data. J. Petrology 19: 463-513.
GEE, R.D., 1971: Geological atlas I mile series. Table Cape, sheet 22 (8016S). Explan. Rept Geol. Surv. Tasm.

GEE, R.D. 1977: Geological atlas 1 mile series. Burnie, sheet $28(8015 \mathrm{~N})$. Explan. Repi Geol. Surv. Tasm.

GLENIE, R.C. \& REED, K.J., 1962: Bores 2 and 3, Portland, Victoria - subsurface geology and engineering data. Mining Geol. Jour. (Vict.) 6(4): $1-10$.

GILL, E.D., 1962: Cainozoic. In SPRY, A.H. \& BANKS, M.R. (Eds): The Geology of Tasmania. J. Geol. Soc. Aust. 9(2): 234-253.

GREEN, D.C., 1976: Isotope geology laboratory report, No.2, 1971-1974. Dept Geol. Mineral. Univ. of Qld (unpubl.).

HARDENBOL, J. \& BERGGREN, W.A., 1978: A new Palaeogene numerical time scale. In COHEE, G.V., GLAESSNER, M.F. \& HEDBERG, H.D. (Eds): CONTRIBUTIONS TO THE GEOLOGIC TIME SCALE. Studies in Geology No.6, Am. Assoc. Petrol. Geol., Tulsa: 213-234.

HARDING, R.R., 1966: Catalogue of age determinations on Australian rocks, 1962-1965. Rept Bur. Min. Resour. Geol. Geophys. Aust. 117.

HOLLIS, J.D. \& SUTHERLAND, F.L., 1985: Occurrences and origins of gem zircons in eastern Australia. Rec. Aust. Mus. 36: 299-311.

JENNINGS, D.J. \& SUTHERLAND, F.L., 1969 Geology of the Cape Portland area with special reference to the Mesozoic (?) appinitic rocks. Tech. Repi Depi Mines Tasm. 13: 45-82.

JOHNSON, R.M., 1888: SYSTEMATIC ACCOUNT OF THE GEOLOGY OF TASMANIA. Government Printer, Hobart.

MATTHEWS, W.L., 1973: Gemstone ocurrences at Sisters Creek. Tech. Rept Dept Mines Tasm. 16: 13-15.

MATTHEWS, W.L., 1974: Geological atlas 1:50,000 series. Lake River, sheet 54 (8314S).

MATTHEWS, W.L., 1983: Geology and ground water resources of the Longford Tertiary basin. Bull. Geol. Surv. Tasm. 59.

McClENAGHAN, M.P. TURNER, N.J., BAILLIE, P.W., BROWN< A.V., WILLIAMS, P.R. \& MOORE, W.R., 1982: Geology of the Ringarooma-Boobyalla area. Bull. Geol. Surv. Tasm. 61 .

MOORE, W.R., BAILLIE, P.W., FORSYTH, S.M. HUDSPETH, J.W., RICHARDSON, R.G. \& TUR NER, N.J., 1984: Boobyalla sub-basin: a Cretaceous onshore extension of the southern edge of Bass Basin. APEA J. 24(1): 110-117.

McDoUgaLL, I., 1959: The Brighton basalts, Tasmania. Pap. Proc. R. Soc. Tasm. 93: 17-28.

NICOLLS, K.D. 1960: Erosion surfaces, river terraces, and river capture in the Launceston Tertiary basin. Pap. Proc. R. Soc. Tasm 94: 1-12.

NYE, P.B., 1924: The sub-basaltic tin deposits of the Ringarooma valley. Bull. Geol. Surv. Tasm. 55. 
NYE, P. B \& BLAKE, F., 1938: The geology and mineral deposits of Tasmania. Bull. Geol. Surv. Tasm. 44.

QUILTY, P.G., 1972: The biostratigraphy of the Tasmanian marine Tertiary. Pap. Proc. R. Soc. Tasm. 106: 25-44.

ROCK, N.M.S., 1981: How should igneous rocks be grouped? Geol. Mag. 118: 449-579.

ROBINSON, V.A., 1974: Geological history of the Bass Basin. APEA J. 14: 45-49.

SPRY, A.H., 1955: The Tertiary rocks of Lower Sandy Bay, Hobart. Pap. Proc. R. Soc. Tasm. 89: 153-168.

SPRY, A.H., 1958: Precambrian rocks of Tasmania, part III. Mersey-Forth area. Pap. Proc. R. Soc. Tasm:: 117-137.

SPRY, A.H., 1962: Igneous activity. In SPRY, A.H. \& BANKS, M.R. (Eds): THE GEOLOGY OF TASMANIA. J. Geol. Soc. Aust. 9(2): 255-284.

SUTHER LAND, F.L., 1969a: A review of the Tasmanian Cainozoic volcanic province. Spec. Publs Geol. Soc. Aust. 2: 133-144.

SUTHERLAND, F.L., 1969b: A comparison of the Cainozoic volcanic provinces of Victoria and Tasmania. Proc. R. Soc, Vict. 82: 179-185.

SUTHERLAND, F.L., 1971 a: The geology and petrology of the Tertiary volcanic rocks of the Tamar Trough, northern Tasmania. Rec. Queen Vict. Mus. 36.

SUTHERLAND, F.L., 1971b: The question of Late Cainozoic uplifts in Tasmania. Search 2: 430-431.

SUTHERLAND, F.L., 1973a: The geological development of the southern shores and islands of Bass Strait. Proc. R. Soc. Vict. 85(2): 133-144.

SUTHERLAND, F.L., 1973b: Igneous rocks, Central Plateau. In BANKS, M.R. (Ed.): THE LAKE COUNTRY OF TASMANIA. R. Soc. Tasm., Hobart: $43-54$

SUTHERLAND, F. L., 1974: High-pressure inclusions in tholeiitic basalt and the range of lherzolitebearing magmas in the Tasmanian volcanic province. Earth Planet. Sci. Lett. 24: 317-324.
SUTHERLAND, F.L., 1976: Cainozoic volcanic rocks. In LEAMAN, D. E: Hobart. Explan. Rept Geol. Surv. Tasm.: 35-56 and Appendix 5: 111 .

SUTHERLAND, F.L., 1977: Cainozoic volca nic rocks. In LEAMAN, D.E.: Brighton. Explan. Rept Geol. Surv. Tasm.: 25-37.

SUTHERLAND, F.L., 1980: Aquagene volcanism in the Tasmanian Tertiary in relation to coastal seas and river systems. Pap. Proc. R. Soc. Tasm. 114: 177-199.

SUTHERLAND, F.L., 1985: Cainozoic volcanic rocks. In FARMER, N.: Geological atlas 1:50,000 series. Kingborough, sheet 88 (8311S). Explan. Repi Geol. Surv. Tasm.: 73-83.

SUTHERLAND, F.L. \& CORBETT, K.D., 1967: The Tertiary volcanic rocks of far north-western Tasmania. Pap. Proc. R. Soc. Tasm. 101: 71-90.

SUTHERLAND, F.L. \& HALE, G.E.A., 1970: Cainozoic volcanism in and around Great Lake, Central Tasmania. Pap. Proc. R. Soc. Tasm. 104: 17-32.

SUTHERLAND, F.L., GREEN, D.C. \& WYATT, B.W. 1973: Ages of the Great Lake basalts, Tasmania, in relation to A ustralian Cainozoic volcanism. $J$. Geol. Soc. Aust. 20: 85-94

TEDFORD, R.H., BANKS, M.R., KEMP, N.R., McDOUGALL, I. \& SUTHERLAND, F.L., 1975: Recognition of the oldest known fossil marsupial from Australia. Nature 225: 141-142.

TWELVETREES, W.H., 1902: On the nomenclature and classification of igneous rocks in Tasmania. Rept Austr. Ass. Adv. Sci:: 264-307.

YIM, W.W.-S., GLEADOW, A.J.W.\& VAN MOORT, J.C., 1985: Fission track dating of alluvial zircons and heavy mineral provenance in Northeast Tasmania. J. Geol. Soc. Lond. 142: 351-356.

(accepted May 9, 1986) 